\title{
EXAMINING STRATEGY DIVERSITY AND INTERDEPENDENCE IN THE MNC'S SUBSIDIARIES AND THEIR FUNCTIONAL ACTIVITIES
}

\author{
Paz Estrella Tolentino, Odile E.M. Janne and Pi-Chi Chen
}

\section{Introduction}

The increasing evolution of multinational corporations (MNCs) into differentiated networks of value-adding activities has presented enormous challenges to the analysis of strategic orientations at various organisational levels of the MNC. As MNCs have adopted less hierarchical and more interdependent strategies and structures, there is doubt about their strategic evolution over time towards a normative (optimal) transnational (Bartlett and Ghoshal, 1989), heterarchical (Hedlund, 1986) or multifocal form (Prahalad and Doz, 1987) (Berggren, 1996; Zander, 2002). The continuing relevance of the (national) foreign subsidiary has also been questioned. Furthermore, there is confusion over what constitutes a MNC's foreign subsidiary, especially since a separate functional value-adding activity may define the subsidiary itself (Birkinshaw and Pedersen, 2009).

We outline these ongoing debates in the next section, and then propose to address the controversies in the context of a resource-based theoretical approach to international strategy that is embedded within a systemic interpretation of the integration-responsiveness (IR) framework in strategic management. The third section contains our propositions concerning the differentiation, interdependence and (co-) evolution towards increasing complexity of the strategy choices of foreign subsidiaries and their functional activities. The study's empirical context is American MNCs in Taiwan's IT industry. The fourth section explains the data and methodology, while the fifth section discusses the empirical results. The concluding section looks at the study's conceptual and empirical implications, limitations as well as avenues for further research.

\section{Debate and theory}

\subsection{MNCs' subsidiary and functional subunits: The debate}

The strategy roles and evolution towards increasing strategic complexity have been defined at different levels of the MNC, but there is little conclusive attempt at linking the corporate to the subsidiary or the subsidiary to the functional activities (Jarillo and Martinez, 1990; Taggart 1997a, 1998; Harzing, 2000; Jindra, 2005). Moreover, the literature focusing on the strategy of distinct 
functional activities has often developed independently from the broader international strategy literature.

On the one hand, specific MNC value-adding activities have become the primary unit of analysis in some studies and the national subsidiary has become irrelevant, especially in developed countries (Birkinshaw and Pedersen, 2009). The argument is that broad subsidiary typologies seem unable to capture the MNC's increasingly fine-sliced specialised network of value chain activities, each with their discrete strategy challenges (Rugman and Verbeke, 2001; Rugman et al., 2011). The challenges of managing innovation are claimed to '... apply to specific businesses, functions and product lines only, and not to all activities of the subsidiary' (Bartlett and Ghoshal, 1990, p. 245). The project level of analysis is sometimes identified as the most relevant focus for study (Whitley, 2006; Andersson et al., 2011).

On the other hand, there are studies that have aggregated at different levels the distinctive effect on, and unique response of, functional activities to global integration (I) and local responsiveness (R) pressures. Prahalad and Doz (1987) imply that such differences among functional activities (or other subunits) can be merged meaningfully at the relevant business unit. Similarly, Ghoshal and Bartlett (1988) combine the responses of all functional/departmental managers to focus on (national) subsidiary-level analysis. The heterogeneity of subsidiaries is often undermined in some other studies that impose conditions on functional activity characteristics in their sample selection, such as manufacturing subsidiaries (Taggart, 1997a/b, 1998; Lin and Hsieh, 2010) or R\&D laboratories (Papanastassiou, 1999).

In emphasising the importance of understanding strategic orientations at various organisational levels of the MNC, we challenge the analytical anachronism of the national subsidiary, defined to include all activities of a MNC in a single country, against the sub-subsidiary unit which is defined as any distinct value-adding activity in that country. The theme of interdependence, rather than autonomy, of strategic orientations is a recurrent one in the subsidiary (Young and Tavares, 2004) and innovation literature, although the relationships between headquarters and subsidiaries, and among subsidiaries has been rather more emphasised.

\subsection{Differentiation and local interdependence: A resource-based approach}

At the heart of the resource-based explanation of the heterogeneous strategy roles of subsidiaries and their functional activities is the representation of the firm as a repository of capabilities that cannot be easily communicated and transferred. The complex role of subsidiaries, and their areas of expertise, has been investigated in the literature on subsidiary-specific competencies (Rugman and Verbeke, 2001), centres of excellence (Frost et al., 2002), internationally integrated laboratories 
(Pearce, 1999), subsidiary R\&D units (Nobel and Birkinshaw, 1998; Kuemmerle, 1999), and (broader) product mandates (Pearce, 1999). Foreign subsidiaries may perform one or several different specialist roles when MNCs attempt to benefit from both location advantages and (internal) network integration (Dunning, 1998; Andersson and Forsgren, 2000; Rugman and Verbeke, 2001). Since strategic roles and competencies can appear in any functional activity, national subsidiary roles may differ from their more specialist competence. The subsidiary may remain part of a tightly integrated relationship with headquarters while having a key area of responsibility for a particular function or product (Roth and Morrison, 1992). Furthermore, a change specific to a functional activity does not necessarily lead to a corresponding change in the subsidiary role (Rugman et al., 2011).

As national subsidiary management focuses on creating value beyond that created collectively by their different functional activities, the quest for strategic integration (Burgelman and Doz, 2001) becomes a form of dynamic capability (Teece et al., 1997). Core technological competencies (Prahalad and Doz, 1987; Prahalad and Hamel, 1990) and organisational capabilities (Bartlett and Ghoshal, 1989; Ghoshal and Bartlett, 1990) define resource-based rationales for strategy interdependence in the multiple organisational levels of the firm. More generally, strategy interdependence in an MNC occurs when the strategy choices at each organisational level influences, and is in turn influenced by, the strategy choices at other organisational levels. While international strategy interdependence within the MNC network has been the subject of much study (Ghoshal and Nohria, 1989; Roth, 1995; O'Donnell, 2000; Subramaniam and Watson, 2006), the national (local) strategy interdependence between the MNC's subsidiaries and their functional activities is far less understood.

There are two ways to discuss strategy interdependence between these MNC subunits. First, the type, strategy role and associated subsidiary characteristics influence the functional activities supported locally by a subsidiary (Roth and Morrison, 1992). Subsidiary roles influence differentiated functional capabilities, procedural justice and performance (Lin and Hsieh, 2010). Most functional activities in locally responsive subsidiaries are independent, and there are also few highly integrated functional activities in global subsidiaries, while many value chain functions in multifocal subsidiaries are coordinated with the parent company and other subsidiaries (Jarillo and Martinez, 1990; Taggart, 1997a). Subsidiary organisational competencies require national managers to reconcile corporate and local concerns (Bartlett and Ghoshal, 1989). Devinney et al. (2000) extended the IR framework to show the diverse organisational forms and strategic choices open to managers for their value chain activities in each international strategic orientation.

Second, the strategy role and associated characteristics of functional activities may influence, or even determine, the role (and evolution) of subsidiaries. Increasing R\&D competencies affect the 
production role of subsidiaries (Papanastassiou, 1999), and the combined R\&D, marketing and production functions the emergence of world product mandate subsidiaries (Rugman and Douglas, 1986). The way the I and R pressures affect functional activities has implications for the ways MNCs organise themselves (Devinney et al., 2000), and therefore the role of foreign subsidiaries. Enright and Subramaniam (2007) proposed a subsidiary role typology based on subsidiary capabilities and scope, which can complement and enrich, rather than compete with, existing typologies based on the IR framework.

\subsection{Multi-level strategic choices: The IR framework}

While the resource-based theoretical approach to strategy and competitive advantage recognises the context specificity in the creation, accumulation and transfer of valuable resources, it is less precise in stipulating the contingencies that make some resources valuable in some context and not in others, particularly when explaining international strategy (Regnér and Zander, 2011). Subunit strategy contexts are likely to vary substantially within the MNC, given diverse environments and managerial perceptions which depend on the kind of activity being performed.

The IR framework, influential in strategic management, identifies the two $\mathrm{I}$ and $\mathrm{R}$ contextual demands which define strategic choice among the strategy alternatives (Prahalad and Doz, 1987). ${ }^{1}$ These include globally integrated (G) (high I-low R), locally responsive (L) (low I-high R), multifocal (M) (high I-high R) and quiescent (Q) (low I-low R) (Taggart, 1998). ${ }^{2}$ The framework has been applied separately at the level of the firm (Bartlett and Ghoshal, 1989), subsidiaries (Bartlett and Ghoshal, 1989; Jarillo and Martinez, 1990; Leong and Tan, 1993; Taggart, 1997a, 1998; Harzing, 2000; Lin and Hsieh, 2010), specific value chain activities (Ghoshal, 1987; Hannon et al., 1995; Tai and Wong, 1998; Solberg, 2000; Jindra, 2005) and businesses (Prahalad and Doz, 1987; Roth and Morrison, 1990).

However, network-based organisations embody complex sets of global and local interactions and strategies well beyond what the simple dichotomy may imply (Buckley and Ghauri, 2004; Iammarino et al., 2009). There are diverse possible associated organisational forms within the modern MNC's integrated network, and there is likely to be differentiation, interdependence and (co) evolution towards increasing complexity of the strategy choices open to managers in the various organisational levels. The IR framework has limited capacity to deal with this, especially when considering how the configuration and interdependencies of the firm's value chain determine the

\footnotetext{
1 We use the terms "strategy role" and "strategy type" interchangeably in this chapter to denote their same meaning.

2 Bartlett (1986) similarly outlined global, multinational and transnational strategies and Bartlett and Ghoshal (1989) included the international strategy.
} 
strategies of the firm and dominant industry characteristics (Devinney et al., 2000; Enright and Subramanian, 2007).

Figure 1.1 provides a systemic interpretation of the IR framework showing the possible heterogeneous strategic choices of the MNC's subsidiary and their functional activities. A subsidiary's strategic choice may embody diverse strategic choices in each constituent value chain activity.

Figure 1.1 Systemic roles of subsidiary and functional units

\begin{tabular}{|c|c|c|c|c|c|c|c|c|c|}
\hline \multirow{12}{*}{$\begin{array}{l}\text { Strategic } \\
\text { choice of } \\
\text { value chain } \\
\text { activities of } \\
\text { foreign } \\
\text { subsidiaries }\end{array}$} & \multirow[t]{2}{*}{$R \& D$} & $\bar{G}$ & $\bar{M}$ & G & $\mathrm{M}$ & $\mathrm{G}$ & $\mathrm{M}$ & $\mathrm{G}$ & $\mathrm{M}$ \\
\hline & & $\mathrm{Q}$ & $\mathrm{L}$ & $\mathrm{Q}$ & $\mathrm{L}$ & $\mathrm{Q}$ & $\mathrm{L}$ & $\bar{Q}$ & $\mathrm{~L}$ \\
\hline & \multirow[t]{2}{*}{ Production } & $\mathrm{G}$ & $\mathrm{M}$ & $\mathrm{G}$ & $\mathrm{M}$ & $\mathrm{G}$ & $\mathrm{M}$ & $\mathrm{G}$ & $\mathrm{M}$ \\
\hline & & $Q$ & $\mathrm{~L}$ & $\mathrm{Q}$ & $\mathrm{L}$ & $\mathrm{Q}$ & $\mathrm{L}$ & $\mathrm{Q}$ & $\mathrm{L}$ \\
\hline & \multirow[t]{2}{*}{ Marketing } & $\mathrm{G}$ & $\bar{M}$ & $\bar{G}$ & $\bar{M}$ & $\bar{G}$ & $\bar{M}$ & $\bar{G}$ & $\bar{M}$ \\
\hline & & $\mathrm{Q}$ & $\mathrm{L}$ & $\mathrm{Q}$ & $\mathrm{L}$ & $\mathrm{Q}$ & $\mathrm{L}$ & $\mathrm{Q}$ & $\mathrm{L}$ \\
\hline & \multirow[t]{2}{*}{ Sales } & $\mathrm{G}$ & $\mathrm{M}$ & $\mathrm{G}$ & $\mathrm{M}$ & $\mathrm{G}$ & $\mathrm{M}$ & $\mathrm{G}$ & $\mathrm{M}$ \\
\hline & & $\mathrm{Q}$ & $\mathrm{L}$ & $\mathrm{Q}$ & $\mathrm{L}$ & $\mathrm{Q}$ & $\mathrm{L}$ & $\mathrm{Q}$ & $\mathrm{L}$ \\
\hline & \multirow{2}{*}{ Services } & $\bar{G}$ & $\mathrm{M}$ & $\bar{G}$ & $\bar{M}$ & $\bar{G}$ & $\mathrm{M}$ & $\bar{G}$ & $\mathrm{M}$ \\
\hline & & Q & $\mathrm{L}$ & Q & $\mathrm{L}$ & $\mathrm{Q}$ & $\mathrm{L}$ & $\mathrm{Q}$ & $\mathrm{L}$ \\
\hline & & \multicolumn{2}{|c|}{$\begin{array}{l}\text { Quiescent } \\
\text { (Q) }\end{array}$} & \multicolumn{2}{|c|}{$\begin{array}{l}\text { Locally } \\
\text { responsive } \\
\text { (L) }\end{array}$} & \multicolumn{2}{|c|}{$\begin{array}{l}\text { Globally } \\
\text { integrated } \\
(\mathrm{G})\end{array}$} & \multicolumn{2}{|c|}{$\begin{array}{c}\text { Multifocal } \\
\text { (M) }\end{array}$} \\
\hline & \multicolumn{9}{|c|}{ Subsidiary strategic choice } \\
\hline
\end{tabular}

Contrary to the environmental contingency perspective, our framework does not offer a deterministic model of the optimum strategy in each context. In embedding a resource-based approach into such a systemic framework we can better understand the non-deterministic differentiation, interdependence and (co-) evolution towards increasing complexity of the strategy choices of foreign subsidiaries and their functional activities.

\section{Propositions}

\subsection{Interdependence}

Some functional activities (typically $R \& D$ and Production) may generally be more globally integrated and less locally responsive than others (such as Marketing, Sales and Service), although a mixed system can be adopted within each functional activity (for example, the R and D in R\&D, design and promotion in Marketing) where specific activities can be more globally integrated or locally responsive depending on the location as well as subsidiary strategy type. To analyse interdependence of strategy choices between subsidiaries and functional activities, it may therefore 
be necessary to define the strategy orientation of functional activities more subtly in terms of their relative emphasis on each I and R dimension separately rather than on their strategy types as shown in Figure 1.1 (Grøgaard, 2012), and we have proceeded on this basis. The analysis of strategy types of subsidiaries remain relevant in this context, although more complex and differentiated in their realisation at sub-subsidiary/ functional level. We propose that the functional activities' relative response to, and influence on, each I and R pressure will vary according to their subsidiary strategy type.

Proposition 1a: There are significant differences in the extent of global integration and local responsiveness of functional activities in accordance with their subsidiary strategy type.

Subsidiaries' competencies are often found highest in the Marketing, Sales and Production functions (Foss and Pedersen, 2004). IT firms, in particular, emphasise downstream activities to foster closer customer relationships and identify market opportunities more effectively (Chen and Tsou, 2012). Foreign subsidiaries in a small economy are also likely to expand sales beyond the domestic market (Hogenbirk and van Kranenburg, 2006). Taiwan's rapidly growing economy and its role as a bridge to mainland China and Southeast Asia have propelled MNCs to respond to the diverse needs of these markets (Fang et al., 2002). Accordingly, the downstream functional activities of IT MNCs in Taiwan may focus on acquiring local market knowledge as a means to expand into other foreign markets. We therefore propose that the relative response of downstream functional activities of IT MNCs in Taiwan to, and influence on, each $\mathrm{I}$ and $\mathrm{R}$ pressure will vary depending on their subsidiary's strategy role.

Proposition 1b: In particular, there are significant differences in the extent of global integration and local responsiveness of downstream functional activities (that is, Marketing, Sales and Services) in accordance with their subsidiary strategy type.

\subsection{Evolution}

The attainment of strategic complexity may not be consistent with the evolution of the MNC towards a 'new model'. Rather, the MNC and their differentiated subunits pursue increasingly complex distinctive combinations of strategic choices which, in the context of the IR framework, are captured less in terms of changing strategy roles but more in terms of increasing levels of the strategy dimensions of I and/or R. Similar to proposition 1a, we therefore propose that functional activities evolve in strategy complexity using differentiated paths which proceed at varying pace, and which will be encouraged, defended and constrained by their subsidiary's role and characteristics, and vice versa. 
Proposition 2: There is a significant difference in the evolution of the strategy orientation of any functional activity towards higher global integration and/or higher local responsiveness in accordance with their subsidiary strategy type.

In particular, the accumulation, creation and transfer of resources associated with the learning of local responsiveness and further integration, a unique systemic benefit of MNC, would in turn imply further strategy interdependence between subsidiaries and their functional activities (Subramaniam and Watson, 2006), reinforcing over time the validity of proposition 1a.

\section{Data and method}

American MNCs in Taiwan's IT industry provide this study's empirical context. The industry receives the most approved private foreign investment in Taiwan and American companies have been the largest foreign investors in recent years (Investment Commission, 2008). Taiwan has become the world's largest supplier of IT-related products and services, and Taiwanese firms have become preferred OEM and ODM ${ }^{3}$ suppliers for global IT industry leaders (Ernst, 2010).

\subsection{Data collection}

The primary sources of data and information were gathered through semi-structured and questionnaire interviews. The sample consisted of 16 American MNCs operating in Taiwan, which are major global players in the IT industry: Agilent Technologies, Advanced Micro Devices (AMD), Avocent, Cisco Systems, Dell, Electronic Data Systems (EDS), Garmin, General Electric (GE), Google, Hewlett-Packard (HP), International Business Machines (IBM), Intel, Microsoft, Motorola, National Instruments (NI) and Sun Microsystems. Each of these MNCs operated a wholly owned foreign subsidiary in Taiwan at the time of the study, performing a broad range of value chain activities. We interviewed all subsidiary managing directors and 100 of their functional unit managers between 2007 and 2008 (see Appendix). Each interview lasted between 60 and 90 minutes. The functional unit managers played leading roles in one of five functional activities in the head offices in Taipei, including R\&D, Production, Marketing, Sales and Service.

\subsection{Measures}

We based the formative I and R constructs partly on Jarillo and Martinez (1990), Taggart (1998) and others, and partly on indicators developed specifically to reflect the peculiar features of Taiwan's IT industry (see Table 1.1). We adapted those indicators for functional activities. All items were 
measured by a 7-point scale ranging from 1=extremely low to 7=extremely high. We developed indices based on the median level of I and R dimensions reported by the respondents. Moreover, we asked all respondents to provide answers relevant to 10 years earlier (in 1997) using their past knowledge of operations. ${ }^{4}$

Table $1.1 \quad$ Measurement of IR dimensions at subsidiary level

\begin{tabular}{|c|c|}
\hline Integration (I) & Responsiveness (R) \\
\hline $\begin{array}{l}\text { 1. Products specified or developed for parent's } \\
\text { market (Prahalad and Doz, 1987; Taggart, } \\
\text { 1998) }\end{array}$ & $\begin{array}{l}\text { 1. Products developed or substantially adapted } \\
\text { to the local environment (Prahalad and Doz, } \\
\text { 1987; Taggart, 1998) }\end{array}$ \\
\hline $\begin{array}{l}\text { 2. Integration of R\&D with parent/regional } \\
\text { headquarters (HQ) (Jarillo and Martinez, } \\
\text { 1990) }\end{array}$ & $\begin{array}{l}\text { 2. Local market area served (Prahalad and Doz, } \\
\text { 1987; Taggart, 1998; Yu, 2000) }\end{array}$ \\
\hline $\begin{array}{l}\text { 3. Integration of production with parent/regional } \\
\text { HQ (Jarillo and Martinez, 1990) }\end{array}$ & $\begin{array}{l}\text { 3. Percentage of inputs that come from } \\
\text { subsidiary (Jarillo and Martinez, 1990) }\end{array}$ \\
\hline $\begin{array}{l}\text { 4. Integration of marketing, sales and service } \\
\text { with parent/regional HQ (Jarillo and } \\
\text { Martinez, 1990) }\end{array}$ & $\begin{array}{l}\text { 4. Percentage of locally produced goods over } \\
\text { total sales (Jarillo and Martinez, 1990) }\end{array}$ \\
\hline $\begin{array}{l}\text { 5. Dependency on linkages within the internal } \\
\text { network (Prahalad and Doz, 1987; Taggart, } \\
\text { 1998) }\end{array}$ & $\begin{array}{l}\text { 5. Proportion of local staff who hold high } \\
\text { positions }(\mathrm{Yu}, 2000)\end{array}$ \\
\hline $\begin{array}{l}\text { 6. Sharing of knowledge within the internal } \\
\text { network (technical knowledge is shared by all } \\
\text { subsidiaries and HQ) (Prahalad and Doz, } \\
\text { 1987; Taggart, 1998; Yu, 2000) }\end{array}$ & $\begin{array}{l}\text { 6. Networking with local research institutions } \\
\text { and suppliers/distributors (Jarillo and } \\
\text { Martinez, 1990) }\end{array}$ \\
\hline $\begin{array}{l}\text { 7. Scope of service which a subsidiary provides } \\
\text { for MNC worldwide market areas } \\
\text { (subsidiaries sell/serve or help to sell/serve } \\
\text { output to the customers of other subsidiaries } \\
\text { of the MNC) (Hood and Young, 1987; } \\
\text { Prahalad and Doz, 1987; Taggart, 1998; Yu, } \\
\text { 2000) }\end{array}$ & \\
\hline
\end{tabular}

We adopted several strategies to enhance data validity and reliability. We described the interview questions and scales carefully, and provided examples during the interviews to ensure uniform

$4 \quad$ All respondents were also asked to reflect on what their answer would have been five years earlier (2002) and the data was consistently similar, but less dramatically different from the 1997 data. 
responses. We adopted a common data collection procedure in every interview. We scrupulously selected and analysed the case study companies with relevant theories and replication logic in a comparative case study. We anchored each construct measure on prior research to minimise errors and biases. We piloted and pre-tested questionnaires to ensure the reliability of prospective answers. We also requested respondents to provide answers based on their recollection of the actual situation 10 years ago (Jarillo and Martinez, 1990; Taggart, 1998), rather than personal estimates. Finally, in order to minimise any potential common method variance (CMV) bias (Malhotra, et al., 2006; Chang et al., 2010), we collected data from different organisational levels (subsidiary and functional units) and at different points in time (in 2007 and 2008). Harman's single-factor test results also indicate that no single factor explains the majority of the variances in the IR variables at the subsidiary and functional activity levels in 2007 and 1997.

\subsection{Data analysis}

We used formative I and R constructs to determine the subsidiary strategy types (Venaik et al., 2004). For each subsidiary, we first calculated a mean of each strategy dimension of I and R. We then applied cluster analysis (Jarillo and Martinez, 1990; Roth and Morrison, 1990; Taggart, 1998), using both hierarchical (Ward) and non-hierarchical (K-means) methods to identify subsidiary strategy type. The Kruskal-Wallis and Mann-Whitney tests determined the existence of significant differences in the strategy dimensions among subsidiaries of different strategy types, and among functional activities belonging to different subsidiary strategy types in 1997 and 2007. We also used qualitative information from interviewees to verify the apparent differentiation, interdependence and evolution towards complexity in the strategic orientations of subsidiaries and functional activities among and within subsidiary strategy types.

\section{Results and discussion}

The cluster analysis identified the existence of a three cluster-solution consisting of seven $\mathrm{M}$, four $\mathrm{G}$ and five $\mathrm{L}$ subsidiaries for the sample. Table 1.2 shows some characteristics of our subsidiary strategy types.

Table 1.2

Membership and characteristics of subsidiary strategy types, 2007

\begin{tabular}{|c|c|c|c|}
\hline \multirow{3}{*}{ Characteristics } & \multicolumn{3}{|c|}{$\begin{array}{c}\text { Subsidiary strategy types } \\
\text { (Members) }\end{array}$} \\
\cline { 2 - 4 } & $\begin{array}{c}\text { Globally Integrated } \\
\text { (Dell, Garmin, Google, } \\
\text { Microsoft) }\end{array}$ & $\begin{array}{c}\text { Locally Responsive } \\
\text { (Avocent, Cisco, } \\
\text { EDS, NI, Sun } \\
\text { Microsystems) }\end{array}$ & $\begin{array}{c}\text { Multifocal } \\
\text { (Agilent, AMD, GE, } \\
\text { HP, IBM, Intel, } \\
\text { Motorola) }\end{array}$ \\
\hline
\end{tabular}




\begin{tabular}{|c|c|c|c|}
\hline $\begin{array}{l}\text { Average age of company } \\
\text { (years) }\end{array}$ & 23 & 28 & 74 \\
\hline $\begin{array}{l}\text { Average age of subsidiary } \\
\text { (years) }\end{array}$ & 15 & 17 & 35 \\
\hline $\begin{array}{l}\text { Average corporate employment } \\
\text { (employee numbers) }\end{array}$ & 50,254 & 49,228 & 174,051 \\
\hline $\begin{array}{l}\text { Average number of locations in } \\
\text { Taiwan (kind/s of functional } \\
\text { activities) }\end{array}$ & $\begin{array}{c}3 \\
\text { (across R\&D, Production, } \\
\text { Sales, Service) }\end{array}$ & $\begin{array}{c}2.7 \\
\text { (more dispersed } \\
\text { Sales and Service } \\
\text { only) } \\
\end{array}$ & $\begin{array}{c}3.7 \\
\text { (across R\&D, } \\
\text { Production, Sales, } \\
\text { Service) } \\
\end{array}$ \\
\hline $\begin{array}{l}\text { Coordination among functional } \\
\text { activities (median) }\end{array}$ & 4.00 & 3.38 & 4.00 \\
\hline $\begin{array}{l}\text { Managerial philosophy shared } \\
\text { within subsidiary (median) }\end{array}$ & 4.17 & 4.00 & 4.00 \\
\hline
\end{tabular}

Note: Values are calculated from the responses obtained.

$\mathrm{G}$ subsidiaries are the youngest and have the highest shared managerial philosophy among their functional activities, which are as tightly coordinated as M subsidiaries. Such coordination is least in $\mathrm{L}$ subsidiaries, and the extent of shared managerial philosophy among functional activities of $\mathrm{L}$ and $\mathrm{M}$ subsidiaries is not as high. The $\mathrm{M}$ subsidiaries tend to be part of larger-sized MNCs and considerably older. Their functional activities are most geographically dispersed in Taiwan.

\subsection{Unit of analysis: Differentiation and interdependence}

Table 1.3 provides evidence of any systematic differences in the strategy dimensions among subsidiaries of different strategy types, and among functional activities belonging to different subsidiary strategy types in 1997 and 2007. The subsidiary strategy types can be differentiated by the extent of I in 1997, and by the extent of both I and R in 2007. Over the period, M subsidiaries have significantly either a high or highest degree of I. In 2007, M subsidiaries also have the significantly highest degree of $\mathrm{R}$, followed by $\mathrm{L}$ and then $\mathrm{G}$ subsidiaries.

The findings at the functional level provide some support for Proposition 1a. Functional activities have different combinations of I that mirror their subsidiary strategy type; and such differences, similar to findings at the subsidiary level, are more sharply defined and statistically significant in 2007 than in 1997. The three subsidiary strategy types could be distinguished in 1997 by the extent of I of Service. Their increasing differentiation by 2007 is evident in the growing extent of I of their downstream activities (Marketing, Sales and Service) and Production, and the degree of R of R\&D. The findings accord with proposition $1 \mathrm{~b}$ which avers that the strategy dimensions of downstream functional activities will particularly distinguish among subsidiary strategy types, although more particularly in their degree of I. 
Figure 1.2 summarises the significant IR strategy dimensions of functional activities according to subsidiary strategy type in a way that is comparable to our proposed model in Figure 1.1. It shows for our sample that, overall, the strategic choices in terms of IR dimensions in each constituent value chain activity (and particularly the I dimension) vary with their subsidiary strategy type.

Figure 1.2 Systemic strategic dimensions of subsidiaries and functional activities, 2007

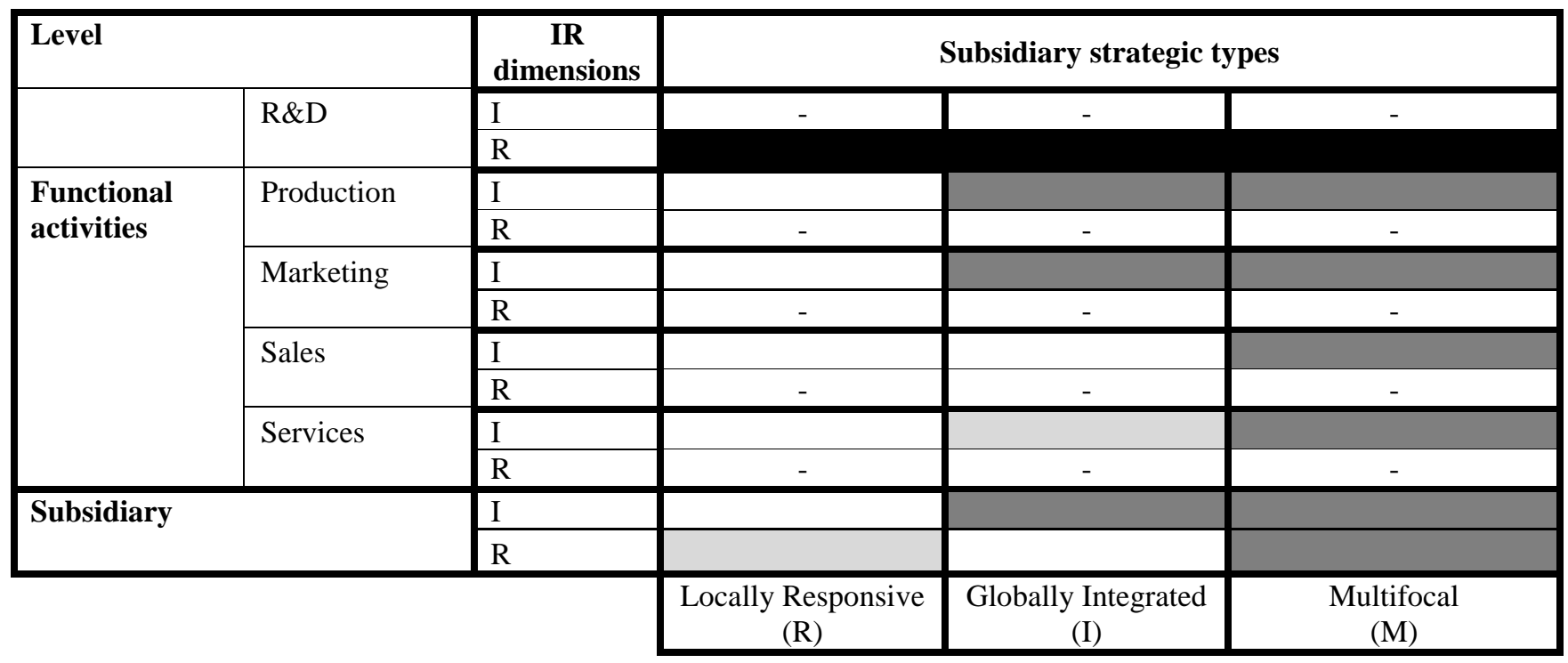

Source: Table 1.3.

Notes: -: no significant difference; black same significant value; dark grey: highest score, light grey: intermediate/second highest score, no colour: lowest score.

To complement the analysis based on aggregated constructs of I and R, Table 1.4 shows how each subsidiary strategy type relates uniquely to their functional activities in terms of disaggregated indicators of I and R. We can significantly distinguish different subsidiary strategy types and their constituent functional activities in terms of almost all indicators of $\mathrm{I}$, and two indicators of $\mathrm{R}$ ('percentage of locally produced goods over total sales' and 'local networking').

Like $M$ subsidiaries, the relative emphasis of $G$ subsidiaries on parent global products and production is evident in their high extent of 'products specified for their parent's market', 'integration of subsidiary production' and 'dependency on linkages within internal network' (I variables 1, 3 and 5). Their R\&D activities are relatively centralised (I variable 2) with most subsidiaries operating R\&D centres to improve their access to Taiwan's ODMs and OEMs. Marketing, Sales and Service are not their core activities and these depend less on internal network linkages than Production (I variable 5), but nevertheless share some knowledge (I variable 6) to support their parent company. These have the lowest level of $\mathrm{R}$ in terms of the 'percentage of locally produced goods over total sales' (subsidiary level), 'proportion of local staff who hold high positions (for Marketing) and extent of 'local networking' (for Sales and Service). 
The L subsidiaries, established to serve Taiwan's market, score the lowest in all significant indicators of I, except in 'sharing of knowledge within the internal network' where they, along with the G subsidiaries, score lower than M subsidiaries. They are most differentiated of all subsidiary strategy types in having the lowest median on 'products specified for parent's market', 'integration of subsidiary production', 'dependency on linkages within internal network' and 'scope of service for MNC worldwide market areas (I variables 1, 3, 5 and 7). Their functional activities, predominantly downstream activities, share the least knowledge and provide the least scope of service for worldwide market areas within the MNC (I variables 6 and 7). The extent of local networking for their Sales and Service is high ( $\mathrm{R}$ variable 6).

Geared to serve corporate global production as well as Taiwan's market, M subsidiaries and their functional activities tend to have a hybrid mix of strong $\mathrm{I}$ and $\mathrm{R}$ characteristics. Similar to $\mathrm{G}$ subsidiaries, M subsidiaries have strong integration of products, production and internal linkages (I variables 1, 3 and 5). Similar to $\mathrm{L}$ subsidiaries, $\mathrm{M}$ subsidiaries have strong local networking ( $R$ variable 6). At functional level, their upstream activities are responsible for global production, and therefore work very closely with their worldwide R\&D and production centres. Subsidiary R\&D is most differentiated of all subsidiary strategy types in having the highest extent of integration with parent/regional HQ (I variable 2). Their Production and Sales seem relatively more focused on global markets than their equivalent in $\mathrm{G}$ and $\mathrm{L}$ subsidiaries (I variable 7), and Production is also most differentiated in having the highest extent of knowledge sharing within the internal network (I variable 6). Their Marketing, Sales and Service uniquely combine significantly high dependence on linkages with high knowledge sharing within the MNC network. Their Marketing and Service also provide a broad scope of services to serve the MNC worldwide market area, comparable to equivalent functions in $\mathrm{G}$ subsidiaries (I variables 5, 6 and 7). Their Sales are differentiated in their highest focus on global products (I variable 1), and local networking ( $\mathrm{R}$ variable 6).

\subsection{Evolution: Differentiation and (co-)evolution}

Table 1.5 provides evidence of any evolution towards strategic complexity by significant increases in the strategy dimensions of $\mathrm{I}$ and/or R among subsidiaries of different strategy types, and among functional activities belonging to different subsidiary strategy types, between 1997 and 2007. The evidence shows that $M$ subsidiaries have evolved the most in complexity with significant increases in both strategy dimensions. All their functional activities also exhibited significantly higher I between 1997 and 2007, and R\&D, Sales and Service remain significantly strong in R. There has also been significantly higher I for most functional activities of $\mathrm{G}$ subsidiaries, as well as higher $\mathrm{R}$ for their Production and Sales. Functional activities of L subsidiaries show the least change towards strategic complexity, with only increased I for R\&D and increased I and R for Sales. The data therefore 
provide some confirmation for Proposition 2 that the evolution towards increasing complexity in the strategy of functional activities varies significantly with their subsidiary strategy type.

\section{Conclusion}

We conceptually and empirically explored the non-deterministic differentiation, interdependence and (co-) evolution towards increasing complexity of the strategy choices of foreign subsidiaries of MNCs and their functional activities. We developed a conceptual framework which embedded a resource-based, dynamic capabilities, perspective within a systemic interpretation of the IR framework. In the context of American MNCs in Taiwan's IT industry, we empirically showed significant differentiation of strategic choices of functional activities, particularly downstream, according to their subsidiary strategy type. Moreover, such differences, similar to findings at the subsidiary level, are more sharply defined and statistically significant in 2007 than in 1997. The evolution towards increasing strategy complexity between 1997 and 2007 have proceeded the farthest in subsidiaries and functional activities of the multifocal type, followed by those of the globally integrated and locally responsive types. The evolution towards strategic complexity suggests further strategy interdependence between subsidiaries and functional activities, and the emergence of MNCs with increasingly differentiated networks of value-adding activities rather than the 'normative' transnational, heterarchical or multifocal MNCs.

Given our finding of interdependence and (co-) evolution of strategic choices of national subsidiary and their functional activities, we challenge the view of the national subsidiary as an endangered analytical species. A subsidiary's strategic type, however, embodies different strategy dimensions rather than strategy types in each constituent functional activity. Multifocal subsidiaries combine the highest levels of R\&D integration, Marketing, Sales and Services dependence on internal network linkages, Production knowledge sharing and Production and Sales provision of a broad scope of services within the MNC with the highest local networking extent of Sales. Service of globally integrated subsidiaries are the least integrated with their parent companies and their Sales less focused on the parent's market; at the same time, their Marketing and Service functions are the least locally responsive in terms of the share of local staff holding senior positions and local networking, respectively. The downstream functional activities of locally responsive subsidiaries, although integrated to some extent, share the least knowledge and provide the narrowest scope of service for worldwide market areas within the MNC. The investigation of such complexity in multi-level strategy choices in the MNC is a promising area for further study.

We recognise some limitations of our study. The relatively small sample size prevented a more thorough testing of the conceptual framework. Other than response bias, there is relative lack of 'more objective' primary and secondary data due to the particular context of Taiwan. A reflective 
methodological approach may be considered in future studies, along with other multivariate multilevel analytical methods. A knowledge-based interpretation of the IR framework may also be explored to explain how the systemic MNC reconciles the I and R pressures through learning and innovation. Future research may also seek to examine the relationship in the strategy choices of foreign subsidiaries and functional activities in other contexts. 
Table 1.3 Comparison of median of overall degrees of integration and responsiveness of subsidiaries and functional activities among different subsidiary strategy types, 1997 and 2007

\begin{tabular}{|c|c|c|c|c|c|c|c|c|}
\hline \multirow{2}{*}{$\begin{array}{l}\text { Functional } \\
\text { activities }\end{array}$} & \multicolumn{3}{|c|}{ Subsidiary strategy types } & \multirow{2}{*}{$\begin{array}{l}\text { Kruskal-Wallis } \\
\text { test } \\
\text { among types } \\
\end{array}$} & \multicolumn{3}{|c|}{ Subsidiary strategy types } & \multirow{2}{*}{$\begin{array}{c}\text { Kruskal-Wallis } \\
\text { test } \\
\text { among types } \\
\end{array}$} \\
\hline & $\begin{array}{c}\text { Globally } \\
\text { integrated }\end{array}$ & $\begin{array}{l}\text { Locally } \\
\text { responsive }\end{array}$ & Multifocal & & $\begin{array}{l}\text { Globally } \\
\text { integrated }\end{array}$ & $\begin{array}{c}\text { Locally } \\
\text { responsive }\end{array}$ & Multifocal & \\
\hline \multicolumn{5}{|c|}{ (1) Degree of integration, 2007} & \multicolumn{4}{|c|}{ (1) Degree of integration, 1997} \\
\hline Subsidiary level: & 5.00 & 4.00 & 5.00 & $.002 * *$ & 4.00 & 4.00 & 5.00 & $.047 *$ \\
\hline \multicolumn{9}{|l|}{ Functional level: } \\
\hline$R \& D(n=21)$ & $6.00(n=7)$ & $6.00(n=4)$ & $6.00(n=10)$ & -5 & $5.00(n=5)$ & $5.00(n=4)$ & $6.00(n=10)$ & .122 \\
\hline $\begin{array}{l}\text { Production } \\
(n=14)\end{array}$ & $6.00(n=3)$ & $5.00(n=1)$ & $6.00(n=10)$ & $.002 * *$ & $5.00(n=3)$ & $5.00(\mathrm{n}=1)$ & $5.00(n=10)$ & - \\
\hline $\begin{array}{l}\text { Marketing } \\
(n=18)\end{array}$ & $6.00(n=5)$ & $5.00(n=5)$ & $6.00(n=8)$ & $.014^{*}$ & $5.00(n=3)$ & $5.00(\mathrm{n}=5)$ & $5.00(\mathrm{n}=8)$ & .655 \\
\hline Sales $(n=21)$ & $5.00(n=4)$ & $5.00(n=6)$ & $6.00(n=11)$ & $.009 * *$ & $4.00(n=3)$ & $4.00(n=6)$ & $4.00(n=11)$ & .664 \\
\hline Service $(n=26)$ & $4.50(n=6)$ & $4.00(n=8)$ & $5.00(\mathrm{n}=12)$ & $.005^{* *}$ & $3.00(n=5)$ & $4.00(n=8)$ & $4.00(n=12)$ & $.054+$ \\
\hline \multicolumn{5}{|c|}{ (2) Degree of local responsiveness, 2007} & \multicolumn{4}{|c|}{ (2) Degree of local responsiveness, 1997} \\
\hline Subsidiary level: & 5.00 & 5.80 & 5.86 & $.007 * *$ & 3.50 & 4.00 & 4.50 & .139 \\
\hline \multicolumn{9}{|l|}{ Functional level: } \\
\hline $\mathrm{R} \& \mathrm{D}$ & 4.00 & 4.00 & 4.00 & $.029 *$ & 4.00 & 4.00 & 4.00 & .361 \\
\hline Production & 4.00 & 4.00 & 4.00 & .819 & 4.00 & 4.00 & 4.00 & .819 \\
\hline Marketing & 4.00 & 4.00 & 4.00 & .273 & 4.00 & 4.00 & 4.25 & .511 \\
\hline Sales & 5.00 & 5.00 & 5.00 & .690 & 4.50 & 5.00 & 5.00 & .153 \\
\hline Service & 5.00 & 5.00 & 5.00 & .678 & 5.00 & 5.00 & 5.00 & .323 \\
\hline
\end{tabular}

Notes: The integration-responsiveness values indicated are average score values calculated from the set of respondents.

Significance: $+p<0.1, * p<0.05, * * p<0.01, * * * p<0.001$

Excluding Google in 1997

$5 \quad$ No sufficient difference. 
Table 1.4 Comparison of median of various indicators of IR dimensions of subsidiaries and functional activities among different subsidiary strategy types, 2007

\begin{tabular}{|c|c|c|c|c|c|c|}
\hline \multirow[t]{2}{*}{ IR indicator: } & & \multicolumn{3}{|c|}{ Subsidiary strategy types } & \multirow{2}{*}{$\begin{array}{l}\text { Kruskal-Wallis } \\
\text { test among types }\end{array}$} & \multirow{2}{*}{$\begin{array}{l}\text { Mann-Whitney test } \\
\text { between pairs }\end{array}$} \\
\hline & & $\begin{array}{c}\text { Globally } \\
\text { integrated }\end{array}$ & $\begin{array}{l}\text { Locally } \\
\text { responsive }\end{array}$ & Multifocal & & \\
\hline \multicolumn{7}{|c|}{ DEGREE OF INTEGRATION (I dimension) } \\
\hline \multicolumn{2}{|c|}{ 1. Products specified for parent's market (subsidiary level) } & 5.00 & 3.00 & 5.00 & $.003 * *$ & $(\mathrm{G}, \mathrm{L})(\mathrm{L}, \mathrm{M})$ \\
\hline \multirow{5}{*}{$\begin{array}{l}\text { Functional } \\
\text { level: }\end{array}$} & $\mathrm{R} \& \mathrm{D}$ & 6.00 & 6.00 & 5.50 & .915 & \multirow{5}{*}{$(\mathrm{G}, \mathrm{M})$} \\
\hline & Production & 7.00 & 7.00 & 5.50 & .122 & \\
\hline & Marketing & 5.00 & 5.00 & 5.50 & .727 & \\
\hline & Sales & 5.00 & 5.00 & 6.00 & $.087+$ & \\
\hline & Service & 4.50 & 5.00 & 5.00 & .545 & \\
\hline \multirow{2}{*}{\multicolumn{2}{|c|}{$\begin{array}{l}\text { 2. Integration of subsidiary R\&D with parent/regional HQ } \\
\text { (subsidiary level) } \\
\text { Integration of your functional activities with parent/regional HQ: }\end{array}$}} & 5.00 & 4.00 & 6.00 & $.003 * *$ & $(\mathrm{G}, \mathrm{M})(\mathrm{L}, \mathrm{M})$ \\
\hline & & & & & & \multirow[b]{6}{*}{$(\mathrm{G}, \mathrm{L})$} \\
\hline & $\mathrm{R} \& \mathrm{D}$ & 6.00 & 6.00 & 6.00 & .146 & \\
\hline & Production & 6.00 & 6.00 & 6.00 & - & \\
\hline & Marketing & 6.00 & 6.00 & 6.00 & .143 & \\
\hline & Sales & 5.00 & 5.00 & 5.00 & - & \\
\hline & Service & 4.50 & 5.00 & 5.00 & $.040 *$ & \\
\hline \multicolumn{2}{|c|}{ 3. Integration of subsidiary production (subsidiary level) } & 5.00 & 4.00 & 5.00 & $.004 * *$ & $(\mathrm{G}, \mathrm{L})(\mathrm{L}, \mathrm{M})$ \\
\hline \multicolumn{2}{|c|}{$\begin{array}{l}\text { 4. Integration of subsidiary marketing, sales and service functions } \\
\text { (subsidiary level) }\end{array}$} & 4.50 & 4.00 & 4.00 & .784 & \\
\hline \multicolumn{2}{|c|}{ 5. Dependency on linkages within internal network (subsidiary level) } & 6.00 & 5.00 & 6.00 & $.092+$ & $(\mathrm{L}, \mathrm{M})$ \\
\hline \multirow{4}{*}{$\begin{array}{l}\text { Functional } \\
\text { level: }\end{array}$} & $\mathrm{R} \& \mathrm{D}$ & 6.00 & 6.00 & 6.00 & .174 & \multirow{4}{*}{$\begin{array}{l}(\mathrm{G}, \mathrm{L})(\mathrm{L}, \mathrm{M}) \\
(\mathrm{G}, \mathrm{M})(\mathrm{L}, \mathrm{M}) \\
(\mathrm{G}, \mathrm{M})(\mathrm{L}, \mathrm{M})\end{array}$} \\
\hline & Production & 6.00 & 5.00 & 6.00 & $.028 *$ & \\
\hline & Marketing & 5.00 & 6.00 & 6.00 & $.045^{*}$ & \\
\hline & Sales & 5.00 & 5.00 & 6.00 & $.001 * *$ & \\
\hline
\end{tabular}

$6 \quad$ Results at $\mathrm{p}<0.1$ 


\begin{tabular}{|c|c|c|c|c|c|c|}
\hline & Service & 4.00 & 4.00 & 5.00 & $.001 * *$ & $(\mathrm{G}, \mathrm{M})(\mathrm{L}, \mathrm{M})$ \\
\hline \multicolumn{2}{|c|}{$\begin{array}{l}\text { 6. Sharing of knowledge within the internal network (subsidiary } \\
\text { level) }\end{array}$} & 5.00 & 5.00 & 6.00 & $.015^{*}$ & $(\mathrm{G}, \mathrm{M})(\mathrm{L}, \mathrm{M})$ \\
\hline \multirow{5}{*}{$\begin{array}{l}\text { Functional } \\
\text { level: }\end{array}$} & $\mathrm{R} \& \mathrm{D}$ & 6.00 & 6.00 & 6.00 & .286 & \\
\hline & Production & 5.00 & 5.00 & 6.00 & $.026 *$ & $(\mathrm{G}, \mathrm{M})(\mathrm{L}, \mathrm{M})$ \\
\hline & Marketing & 6.00 & 4.00 & 6.00 & $.003 * *$ & $(\mathrm{G}, \mathrm{L})(\mathrm{L}, \mathrm{M})$ \\
\hline & Sales & 5.50 & 5.00 & 6.00 & $.005^{* *}$ & $(\mathrm{G}, \mathrm{L})(\mathrm{L}, \mathrm{M})$ \\
\hline & Service & 5.00 & 4.00 & 5.00 & $.000^{* * *}$ & $(\mathrm{G}, \mathrm{L})(\mathrm{L}, \mathrm{M})$ \\
\hline \multicolumn{2}{|c|}{$\begin{array}{l}\text { 7. Scope of service which a subsidiary serves for MNC worldwide } \\
\text { market areas (subsidiary level) }\end{array}$} & 4.50 & 4.00 & 5.00 & $.090+$ & $(\mathrm{G}, \mathrm{L})(\mathrm{L}, \mathrm{M})$ \\
\hline \multirow{5}{*}{$\begin{array}{l}\text { Functional } \\
\text { level: }\end{array}$} & $\mathrm{R} \& \mathrm{D}$ & 6.00 & 6.00 & 6.00 & $.094+$ & \\
\hline & Production & 5.00 & 5.00 & 6.00 & $.019^{*}$ & $(\mathrm{G}, \mathrm{M})(\mathrm{L}, \mathrm{M})$ \\
\hline & Marketing & 6.00 & 4.00 & 6.00 & $.008 * *$ & $(\mathrm{G}, \mathrm{L})(\mathrm{L}, \mathrm{M})$ \\
\hline & Sales & 5.00 & 5.00 & 6.00 & $.001 * *$ & $(\mathrm{G}, \mathrm{M})(\mathrm{L}, \mathrm{M})$ \\
\hline & Service & 5.00 & 4.00 & 5.00 & $.000 * * *$ & $(\mathrm{G}, \mathrm{L})(\mathrm{L}, \mathrm{M})$ \\
\hline \multicolumn{7}{|c|}{ DEGREE OF LOCAL REPONSIVENESS (R dimension) } \\
\hline \multicolumn{2}{|c|}{$\begin{array}{l}\text { 1. Products are developed or substantially adapted to the local } \\
\text { environment (subsidiary level) }\end{array}$} & 5.00 & 6.00 & 6.00 & .162 & \\
\hline \multicolumn{7}{|c|}{ Functional activities are developed or adapted to the local } \\
\hline \multirow[t]{5}{*}{ environment: } & $\mathrm{R} \& \mathrm{D}$ & 5.00 & 5.00 & 5.00 & .611 & \\
\hline & Production & 5.00 & 6.00 & 5.00 & .113 & \\
\hline & Marketing & 5.00 & 5.00 & 5.00 & .477 & \\
\hline & Sales & 5.00 & 5.00 & 5.00 & 690 & \\
\hline & Service & 5.00 & 5.00 & 5.00 & - & \\
\hline \multicolumn{2}{|c|}{ 2. Local market area served (subsidiary level) } & 4.50 & 5.00 & 5.00 & .141 & \\
\hline \multirow{5}{*}{$\begin{array}{l}\text { Functional } \\
\text { level: }\end{array}$} & $\mathrm{R} \& \mathrm{D}$ & 5.00 & 5.00 & 5.00 & .937 & \\
\hline & Production & 5.00 & 6.00 & 6.00 & .504 & \\
\hline & Marketing & 5.00 & 5.00 & 5.50 & .595 & \\
\hline & Sales & 5.00 & 5.00 & 5.00 & .751 & \\
\hline & Service & 5.50 & 5.00 & 5.00 & .796 & \\
\hline
\end{tabular}




\begin{tabular}{|c|c|c|c|c|c|c|}
\hline \multicolumn{2}{|c|}{ 3. Percentage of inputs that come from the local (subsidiary level) } & \multirow{2}{*}{$\frac{5.00}{3.00}$} & \multirow{2}{*}{$\begin{array}{l}6.00 \\
4.00\end{array}$} & \multirow{2}{*}{$\frac{6.00}{3.50}$} & \multirow{2}{*}{$\begin{array}{r}.824 \\
.344\end{array}$} & \\
\hline $\begin{array}{l}\text { Functional } \\
\text { level: }\end{array}$ & $\mathrm{R} \& \mathrm{D}$ & & & & & \\
\hline & Production & 4.00 & 4.00 & 3.50 & .236 & \\
\hline & Marketing & 3.00 & 3.60 & 4.00 & .214 & \\
\hline & Sales & 4.50 & 5.00 & 5.00 & .192 & \\
\hline & Service & 5.00 & 5.00 & 5.00 & .123 & \\
\hline \multicolumn{2}{|c|}{$\begin{array}{l}\text { 4. Percentage of locally produced goods over total sales (subsidiary } \\
\text { level) }\end{array}$} & 4.50 & 5.00 & 6.00 & $.049 *$ & $(\mathrm{G}, \mathrm{M})(\mathrm{L}, \mathrm{M})$ \\
\hline \multirow{5}{*}{$\begin{array}{l}\text { Functional } \\
\text { level: }\end{array}$} & $\mathrm{R} \& \mathrm{D}$ & 3.00 & 4.00 & 4.00 & .104 & \\
\hline & Production & 3.00 & 4.00 & 4.00 & .113 & \\
\hline & Marketing & 4.00 & 4.00 & 4.00 & $.063+$ & \\
\hline & Sales & 5.00 & 4.50 & 5.00 & $.003 * *$ & $(\mathrm{G}, \mathrm{L})(\mathrm{L}, \mathrm{M})$ \\
\hline & Service & 5.00 & 5.00 & 5.00 & - & \\
\hline \multirow{6}{*}{$\begin{array}{l}\text { 5. Proportion } \\
\text { Functional } \\
\text { level: }\end{array}$} & staff who hold high positions (subsidiary level) & 5.50 & 6.00 & 6.00 & .424 & \\
\hline & $\mathrm{R} \& \mathrm{D}$ & 3.00 & 4.00 & 3.50 & .229 & \\
\hline & Production & 3.00 & 4.00 & 4.00 & .261 & \\
\hline & Marketing & 3.00 & 4.00 & 4.00 & $.012 *$ & $(\mathrm{G}, \mathrm{L})(\mathrm{G}, \mathrm{M})$ \\
\hline & Sales & 4.50 & 5.00 & 5.00 & .478 & \\
\hline & Service & 5.00 & 5.00 & 5.00 & .316 & \\
\hline \multicolumn{2}{|c|}{ 6. Local networking (subsidiary level) } & 5.50 & 6.00 & 6.00 & $.052+$ & $(\mathrm{G}, \mathrm{L})(\mathrm{G}, \mathrm{M})$ \\
\hline \multirow{5}{*}{$\begin{array}{l}\text { Functional } \\
\text { level: }\end{array}$} & $\mathrm{R} \& \mathrm{D}$ & 4.00 & 4.00 & 4.00 & - & \\
\hline & Production & 4.00 & 4.00 & 4.00 & - & \\
\hline & Marketing & 4.00 & 4.00 & 4.00 & - & \\
\hline & Sales & 5.00 & 5.50 & 6.00 & $.001 * *$ & $(\mathrm{G}, \mathrm{M})(\mathrm{L}, \mathrm{M})$ \\
\hline & Service & 5.00 & 6.00 & 6.00 & $.000 * * *$ & $(\mathrm{G}, \mathrm{L})(\mathrm{G}, \mathrm{M})$ \\
\hline
\end{tabular}

Notes: The integration-responsiveness values indicated are average score values calculated from the set of respondents.

Significance: $+\mathrm{p}<0.1, * \mathrm{p}<0.05, * * \mathrm{p}<0.01, * * * \mathrm{p}<0.001$

Subsidiaries: $\mathrm{G}=$ globally integrated, $\mathrm{L}=$ locally responsive, $\mathrm{M}=$ multifocal

Bold: most differentiated between pairs. 
Table 1.5 Comparison of median of overall degrees of integration and responsiveness of subsidiaries and functional activity within different subsidiary strategy types, 1997 and 2007

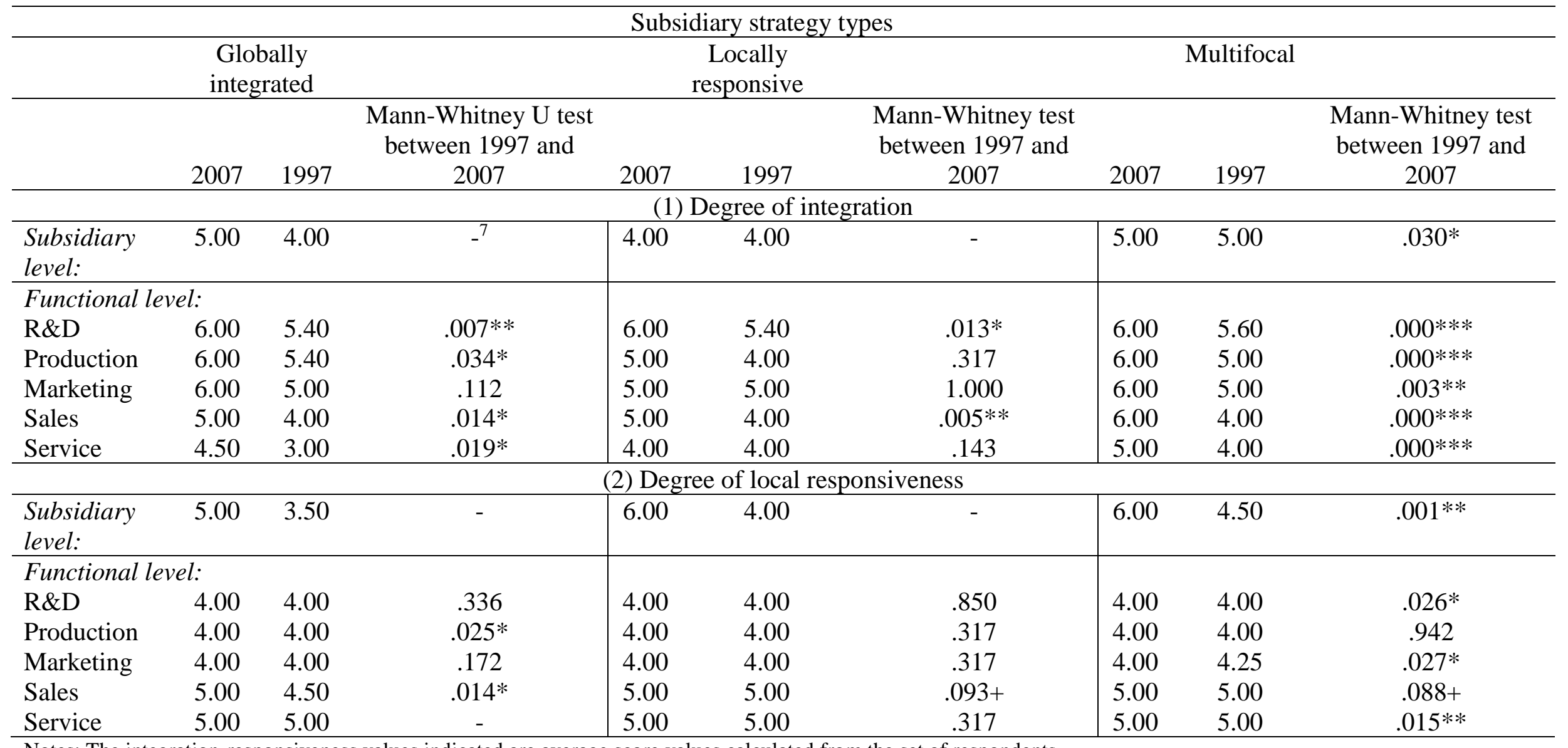

Notes: The integration-responsiveness values indicated are average score values calculated from the set of respondents.

Significance: $+\mathrm{p}<0.1, * \mathrm{p}<0.05, * * \mathrm{p}<0.01, * * * \mathrm{p}<0.001$

Excluding Google in 1997.

\footnotetext{
$7 \quad$ No sufficient difference.
} 


\section{References}

Andersson, U. and Forsgren, M. (2000) 'In Search of Centre of Excellence: Network Embeddedness and Subsidiary Roles in Multinational Corporations', Management International Review, 40, 329-50.

Andersson, U., Mudambi, R. and Persson, M. (2011) Unpacking Lateral Knowledge Transfer in Multinational Corporations. International Business Conference. Reading, UK, 11-12 April 2011.

Bartlett, C.A. (1986) 'Building and Managing the Transnational: The New Organizational Challenge' in M. E. Porter (ed.), Competition in Global Industries (Boston: Harvard Business School Press).

Bartlett, C.A. and Ghoshal, S. (1989) Managing Across Borders: The Transnational Solution (Boston: Harvard Business School Press).

Bartlett, C.A. and Ghoshal, S. (1990) 'Managing Innovation in Transnational Corporations' in C.A. Bartlett, Y. Doz and G. Hedlund (eds.) Managing the Global Firm (London: Routledge).

Berggren, C. (1996) 'Building a Truly Global Organization? ABB and the Problems of Integrating a Multidomestic Enterprise', Scandinavian Journal of Management, 12, 123-37.

Birkinshaw, J. and Pedersen, T. (2009) 'Strategy and Management in MNE Subsidiaries', in A.M. Rugman (ed.) Oxford Handbook of International Business, $2^{\text {nd }}$ edn (Oxford: Oxford University Press).

Brock, D.M. and Birkinshaw, J. (2004) 'Multinational Strategy and Structure: A Review and Research Agenda', Management International Review, 44, 5-14.

Buckley, P.J. and Ghauri, P.N. (2004) 'Globalisation, Economic Geography and the Strategy of Multinational Enterprises', Journal of International Business Studies, 35, 81-98.

Burgelman, R.A. and Doz, Y.L. (2001) 'The Power of Strategic Integration', MIT Sloan Management Review, 42, 28-38.

Chang, S-J., van Witteloostuijn, A. and Eden, L. (2010) 'From the Editors: Common Method Variance in International Business Research', Journal of International Business Studies, 41, 178-84.

Chen, J-S. and Tsou, H-T. (2012) 'Performance Effects of IT Capability, Service Process Innovation, and the Mediating Role of Customer Service', Journal of Engineering and Technology Management, 29, 71-94.

Devinney, T.M., Midgley, D.F. and Venaik, S. (2000) 'The Optimal Performance of the Global Firm: Formalizing and Extending the Integration-Responsiveness Framework', Organization Science, 11, 674-95.

Dunning, J.H. (1998) 'Location and the Multinational Enterprise: A Neglected Factor?', Journal of International Business Studies, 29, 45-66.

Enright, M.J. and Subramanian, V. (2007) 'An Organizing Framework for MNC Subsidiary Typologies', Management International Review, 47, 895-924.

Ernst, D. (2010) 'Upgrading through Innovation in a Small Network Economy: Insights from Taiwan's IT Industry', Economics of Innovation and New Technology, 19, 295-324.

Fang, S-C., Lin, J. L., Hsiao, L.Y.C., Huang, C-M. and Fang, S-R. (2002) 'The Relationship of Foreign R\&D Units in Taiwan and the Taiwanese Knowledge-Flow System', Technovation, 22, 371-83.

Foss, N.J. and Pedersen, T. (2004) 'Organizing Knowledge Processes in the Multinational Corporation: An Introduction', Journal of International Business Studies, 35, 340-9.

Frost, T.S., Birkinshaw, J.M. and Ensign, P.C. (2002) 'Centers of Excellence in Multinational Corporations’, Strategic Management Journal, 23, 997-1018. 
Ghoshal, S. (1987) 'Global Strategy: An Organizing Framework', Strategic Management Journal, 8, 425-40.

Ghoshal, S. and Bartlett, C.A. (1988) 'Creation, Adoption, and Diffusion of Innovations by Subsidiaries of Multinational Corporations', Journal of International Business Studies, $19,365-88$.

Ghoshal, S. and Bartlett, C.A. (1990) 'The Multinational Corporation as an Interorganizational Network', Academy of Management Review, 15, 603-625.

Ghoshal, S. and Nohria, N. (1989) 'Internal Differentiation within Multinational Corporations', Strategic Management Journal, 10, 323-37.

Grøgaard, B. (2012) 'Alignment of Strategy and Structure in International Firms: An Empirical Examination', International Business Review, 21, 397-407.

Hannon, J.M., Huang, I-C. and Jaw, B-S. (1995) 'International Human Resource Strategy and its Determinants: The Case of Subsidiaries in Taiwan', Journal of International Business Studies, 26, 531-54.

Harzing, A. (2000) 'An Empirical Analysis and Extension of the Bartlett and Ghoshal Typology of Multinational Companies', Journal of International Business Studies, 31, 101-20.

Hedlund, G. (1986) 'The Hypermodern MNC - A heterarchy?', Human Resource Management, 25, 9-25.

Hogenbirk A.E. and van Kranenburg, H.L. (2006) 'Roles of Foreign Owned Subsidiaries in a Small Economy', International Business Review, 15, 53-67.

Hood, N. and Young, S. (1987) 'Inward Investment and the EC: UK Evidence on Corporate Integration Strategies', Journal of Common Market Studies, 26, 193-206.

Iammarino, S., Janne, O.E.M. and McCann, P. (2009) 'Multinational Firms and Technological Innovation: The 'Global versus Local' Challenge' in M. Farshchi, O.E.M. Janne and P. McCann (eds.) Technological Change and Mature Industrial Regions: Firms, Knowledge and Policy (Cheltenham: Edward Elgar).

Investment Commission (2008) Statistics on Approved Foreign Investment by Country (Taiwan: Ministry of Economic Affairs).

Jarillo, J.C. and Martinez, J.L. (1990) 'Different Roles for Subsidiaries: The Case of Multinational Corporations in Spain', Strategic Management Journal, 11, 501-12.

Jindra, B. (2005) 'A Strategy View on Knowledge in the MNE - Integrating Subsidiary Roles and Knowledge Flows', East-West Journal of Economics and Business, VIII, 43-72.

Kuemmerle, W. (1999) 'The Drivers of Foreign Direct Investment into Research and Development - An Empirical Investigation', Journal of International Business Studies, 30, 1-24.

Leong, S.M. and Tan, C.T. (1993) 'Managing Across Borders: An Empirical Test of the Bartlett and Ghoshal [1989] Organizational Typology', Journal of International Business Studies, 24, 449-64.

Lin, S-L. and Hsieh, A-T. (2010) 'International Strategy Implementation: Roles of Subsidiaries, Operational Capabilities, and Procedural Justice, Journal of Business Research, 63, 52-9.

Malhotra, N., Kim Sung, S. and Patil, A. (2006) 'Common Method Variance in IS Research: A Comparison of Alternative Approaches and a Reanalysis of Past Research', Management Science, 52, 1865-83.

Nobel, R. and Birkinshaw J. M. (1998) 'Patterns of Control and Communication in International Research and Development Units', Strategic Management Journal, 19, 479-98.

O'Donnell, S.W. (2000) 'Managing Foreign Subsidiaries: Agents of Headquarters, or an Interdependent Network?', Strategic Management Journal, 21, 525-48. 
Papanastassiou, M. (1999) 'Technology and Production Strategies of Multinational Enterprise (MNE) Subsidiaries in Europe', International Business Review, 8, 213-32.

Paterson, S.L. and Brock, D.M. (2002) 'The Development of Subsidiary-Management Research: Review and Theoretical Analysis', International Business Review, 11, 13963.

Pearce, R. (1999) 'The Evolution of Technology in Multinational Enterprises: The Role of Creative Subsidiaries', International Business Review, 8, 125-48.

Prahalad, C.K. and Doz, Y.L. (1987) The Multinational Mission: Balancing Local Demands and Global Vision (New York: The Free Press).

Prahalad, C.K. and Hamel, G. (1990) 'The Core Competence of the Corporation', Harvard Business Review, 68, 79-91.

Regnér, P. and Zander, U. (2011) 'Knowledge and Strategy Creation in Multinational Companies. Social-Identity Frames and Temporary Tension in Knowledge Combination', Management International Review, 51, 821-50.

Roth, K. (1995), 'Managing International Interdependence: CEO Characteristics in a Resource-Based Framework', The Academy of Management Journal, 38, $200-31$.

Roth, K. and Morrison, A.J. (1990) 'An Empirical Analysis of the IntegrationResponsiveness Framework in Global Industries', Journal of International Business Studies, 41, 541-64.

Roth, K. and Morrison, A.J. (1992) 'Implementing Global Strategy: Characteristics of Global Subsidiary Mandates', Journal of International Business Strategy, 23, 715-35.

Rugman, A. and Douglas, S. (1986) 'The Strategic Management of Multinationals and World Product Mandating', Canadian Public Policy - Analyse de Politique, XII, 320-28.

Rugman, A. and Verbeke, A. (2001) 'Subsidiary-Specific Advantages in Multinational Enterprises’, Strategic Management Journal, 22, 237-50.

Rugman, A., Verbeke A. and Yan, W. (2011) 'Re-conceptualizing Bartlett and Ghoshal's Classification of National Subsidiary Roles in the Multinational Enterprise', Journal of Management Studies, 48, 253-77.

Solberg, C.A. (2000) 'Educator Insights. Standardisation or Adaptation on the International Marketing Mix: The Role of the Local Subsidiary/Representative', Journal of International Marketing, 8, 78-9.

Subramaniam, M. and Watson, S. (2006) 'How Interdependence Affects Subsidiary Performance', Journal of Business Research, 59, 916-24.

Taggart, J.H. (1997a) 'An Evaluation of the Integration-Responsiveness Framework: MNC Manufacturing Subsidiaries in the UK', Management International Review, 37, 295318.

Taggart, J.H. (1997b) 'R\&D Complexity in UK Subsidiaries of Manufacturing Multinational Corporations', Technovation, 17, 73-82.

Taggart, J.H. (1998) 'Strategy Shifts in MNC Subsidiaries', Strategic Management Journal, $19,663-81$.

Tai, S.H.C. and Wong, Y.H. (1998) "Advertising Decision Making in Asia: "Glocal" versus "Regcal" Approach', Journal of Managerial Issues, 10, 318-39.

Teece, D.J., Pisano, G., and Shuen, A. (1997) 'Dynamic Capabilities and Strategic Management', Strategic Management Journal, 18, 509-33.

Venaik, S., Midgley, D.F. and Devinney, T.M. (2004) 'A New Perspective on the IntegrationResponsiveness Pressures Confronting Multinational Firms', Management International Review, 44, 15-48.

Whitley, R. (2006) 'Project-Based Firms: New Organizational Form or Variations on a Theme?', Industrial and Corporate Change, 15, 77-99. 
Young, S. and Tavares, A.T. (2004) 'Centralization and Autonomy: Back to the Future', International Business Review, 13, 215-237.

$\mathrm{Yu}$, M-C. (2000) A Study of Organizational Configuration, Strategy, and Control in Multinational Corporations. Ph.D. thesis. Taiwan, National Cheng Kung University.

Zander, I. (2002) 'The Formation of International Innovation Networks in the Multinational Corporation: An Evolutionary Perspective', Industrial and Corporate Change, 11, 327 53. 
Appendix: Number of interviews conducted with functional unit managers of foreign subsidiaries of American MNCs in Taiwan's IT industry

\begin{tabular}{|l|l|c|c|c|c|c|c|}
\hline & \multicolumn{1}{|c|}{ Subsidiary/Function } & R\&D & Production & Marketing & Sales & Service & Total \\
\hline 1. & Agilent Technologies & 1 & 1 & 1 & 1 & 2 & 6 \\
\hline 2. & AMD & 1 & 1 & 1 & 1 & 1 & 5 \\
\hline 3. & Avocent & $\mathrm{X}$ & $\mathrm{X}$ & 1 & 2 & 2 & 5 \\
\hline 4. & Cisco Systems & 1 & 1 & 1 & 1 & 2 & 6 \\
\hline 5. & Dell & 2 & 2 & 1 & 1 & 1 & 7 \\
\hline 6. & Electronic Data Systems & 1 & $\mathrm{X}$ & 1 & 1 & 2 & 5 \\
\hline 7. & Garmin & 1 & 1 & 1 & 1 & 2 & 6 \\
\hline 8. & GE & 1 & 2 & 1 & 2 & 1 & 7 \\
\hline 9. & Google & 2 & $\mathrm{X}$ & 2 & 1 & 1 & 6 \\
\hline 10. & HP & 2 & 2 & 1 & 2 & 2 & 9 \\
\hline 11. & IBM & 2 & 2 & 2 & 2 & 3 & 11 \\
\hline 12. & Intel & 2 & 1 & 1 & 2 & 1 & 7 \\
\hline 13. & Microsoft & 2 & $\mathrm{X}$ & 1 & 1 & 2 & 6 \\
\hline 14. & Motorola & 1 & $\mathrm{X}$ & 1 & 1 & 2 & 6 \\
\hline 15. & NI & Sun Microsystems & 1 & 1 & 1 & 1 & 4 \\
\hline 16. & Total & & & & & \\
\hline
\end{tabular}

Note: X means that no such operations exist in the subsidiaries. 